\title{
Penunjang Keputusan Dalam Kelayakan Pemberian Kredit Motor Pada Mandala Multifinance
}

\author{
Sarwindah ${ }^{* 1}$, Marini ${ }^{2}$ \\ ${ }^{1}$ Program Studi Bisnis Digital, ${ }^{2}$ Program Studi Sistem Informasi, ISB Atma Luhur \\ J1.Jend Sudirman Selindung Pangkalpinang- Bangka Belitung \\ e-mail:*11indah_syifa@ atmaluhur.ac.id, 2arinimarini44@atmaluhur.ac.id
}

\begin{abstract}
Abstrak
PT Mandala Multi Finance merupakan perusahan leasing yang bergerak dibidang jasa kredit motor bagi pemohon kredit dan mengambil keuntungan dari pembayaran bunga kredit. Pada dasarnya perusahaan leasing merekrut tenaga kerja dibagian credit analyst untuk melakukan analisis terhadap kemampuan membayar pemohon kredit dan melakukan surveylapangan untuk mengurangi kemacetan dalam membayar kredit. Seorang Credit Analyst diharapkan untuk bekerja cepat dan teliti dalam menganalisa banyaknya data pemohon kredit yang masuk sehingga tidak menutup kemungkinan terjadi kesalahan-kesalan, seperti kesalahan perhitungan, kesalahan membaca data, dan lain-lain. Oleh karena itu dalam upaya membantu CreditAnalyst dalam kegiatan pengambilan keputusan konsumen layak kredit, diperlukan model sistem berbasis komputer yang dapat memberikan kemudahan dalam melakukan analisa data, perhitungan penilaian kriteria pemohon kredit, serta membantu pengolahan data menjadi informasi untuk mengambil keputusan dari masalah tersebut. Sebuah sistem penunjang keputusan merupakan pilihan tepat untuk membantu penyeleksian pemohon kredit dimanasistem penunjang keputusan ini dirancang dengan menggunakan metode AHP, pembuatan sistem menggunakan bahasa pemogramanphp dan databasemysql. Hasil berdasarkan Matrik Faktor Pembobotan HirarkiUntukSemuaKritera yang dinormalkan pembobotan hirarki untuk semua kriteria dengan unsur-unsur pada tiap kolom dibagi dengan jumlah total pada kolom yang bersangkutan, maka akan diperoleh bobot relatif yang dinormalkan. Nilai vektor eigen dihasilkan dari rata-rata nilai bobot relatif untuk tiap baris menunjukan bahwa kriteria yang paling penting bagi nasabah yang ingin mengajukan pengajuan kredit. Penghasilan dengan bobot 0,649 atau 64,9\%, kemudian disusul Kartu keluarga dengan nilai bobot 0,088 atau 8,8 $\%$, dan Domisili adalah 0,21 atau $21 \%$.
\end{abstract}

Kata kunci-PenunjangKeputusan, PemberianKredit, Credit Analyst, leasing dan AHP.

\begin{abstract}
PT Mandala Multi Finance is a leasing company engaged in motorcycle loan services for loan applicants and takes advantage of loan interest payments. Basically, leasing companies recruit workers in the credit analyst section to analyze the ability to pay credit applicants and conduct field surveys to reduce credit defaults. ACredit Analyst is expected to work quickly and thoroughly in analyzing the amount of incoming credit applicant data so that it does not close the possibility of errors, such as miscalculations, errors in reading data, and others. Therefore, in an effort to help Credit Analysts in credit-worthy consumer decision-making activities, a computer-based system model is needed that can provide convenience in analyzing data, calculating credit applicants' assessment criteria, and helping processing data into information to make decisions about the problem. A decision support system is the right choice to help select credit applicants where the decision support system is designed using the AHP method, making the system using php programming language and MySQL database. Results based on the Hierarchy Weighting Factor Matrix For all normalized criteria for the weighting of the hierarchy for all criteria with the elements in each column divided by the total number in the
\end{abstract}


column concerned, then the normalized relative weight will be obtained. The eigenvector value generated from the average value of relative weights for each row shows that the criteria are most important for customers who want to apply for credit. Income with a weight of 0.649 or $64.9 \%$, then followed by a family card with a weight value of 0.088 or $8.8 \%$, and Domicile is 0.21 or $21 \%$.

Keyword : Decision Support, Credit Provision, Credit Analyst and AHP.

\section{PENDAHULUAN}

$P_{k}$ T. Mandala Multifinance adalah Perusahaan leasing berdasarkan Keputusan Menteri Keuangan RI No. 323/KMK.017/1997 pada tanggal 21 Juli 1997. Berdasarkan keputusan tersebut, kegiatan usaha Perusahaan meliputi Sewa GunaUsaha, Anjak Piutang, Usaha Kartu Kredit, dan Pembiayaan Konsumen. Sampai saat ini Perusahaan memfokuskan diri pada kegiatan usaha pembiayaan konsumen, khususnya pembiayaan kendaraan roda dua. Perusahaan memegang teguh berkomitmen untuk memberikan pelayanan terbaik terhadap konsumen dan mitra bisnis, melalui pelayanan optimal yang didukung oleh pengelolaan sumber daya manusia yang terarah, terpadu dan berkesinambungan, serta ketersediaan infrastruktur yang memadai. Banyaknya pemohon kredit yang mengajukan kredit dengan kondisi ekonomi yang berbedabeda menuntut kejelian Credit Analyst dalam pengambilan keputusan.

Sistem yang berjalan saat ini, Kriteria yang dijadikan acuan dalam pengambilan keputusan pemberian kelayakan kredit kepada konsumen kredit oleh bagian Credit Analyst yaitu kepribadian pemohon kredit, kemampuan membayar pemohon kredit (slip gaji), Jumlah tanggungan (kartu keluarga), uang muka pemohon kredit dan jaminan pemohon. Sistem ini belum berjalan dengan baik karena masih terdapatnya beberapa konsumen yang memiliki kredit macet seperti pembayaran kredit yang terlambat maupun pembayaran kredit yang tidak di bayarkan oleh konsumen sehingga menyebabkan berkurangnya profit perusahaan leasing. Dalam upaya membantu Credit Analyst dalam kegiatan pengambilan keputusan konsumen layak kredit, maka diperlukan sebuah model system pendukung keputusan berbasis computer yang dapat memberikan kemudahan dalam melakukan analisa.

Perhitungan penilaian kriteria pemohon kredit dengan menentukan perubahan acuan kriteria penilaian kelayakan kredit yaitu penghasilan (slip gaji), Jumlah Tanggungan (Kartu keluarga), Domisi (KTP). Dalam penelitian ini system dibuat menggunakan bahasa pemograman PHP dan database Mysql dengan metode pengembangan perangkat lunak System Development Life Cycle (SDLC) yang memiliki tahapan pengembangan yaitu Tahapan Analisa Kebutuhan Sistem, Tahapan Perancangan Sistem, Tahapan Desain Sistem, dan Tahapan Implementasi Sistem. Manfaat dari penelitian ini adalah untuk membantu Credit Analyst dalam kegiatan pengambilan keputusan konsumen layak kredit. Tujuan yang ingin dicapai pada peneltian ini adalah untuk membuat system pendukung keputusan pemberian kelayakan kredit kepada konsumen dengan menerapkan kriteria penilaian kelayakan kredit yaitu penghasilan (slip gaji), jumlah tanggungan (kartu keluarga), domisi (KTP) disertai bobot penilaian pada setiap kriteria.

\subsection{Penelitihan Terdahulu}

[1] Pada penelitian yang dilakukan oleh Amardyah Amborowati (2004). Sistem Penunjang Keputusan Pemilihan Perumahan dengan Metode AHP menggunakan Expert Choice.

Sarwindah, et., al (Penunjang Keputusan Dalam Kelayakan Pemberian Kredit Motor Pada Mandala Multifinance) 
Sistem Penunjang Keputusan Pemilihan dengan skoring melalui kuesioner dan diolah menggunakan metode AHP dengan Process Analytical methods using a software expert choice bahwa kebutuhan akan perumahan KPR sangat penting bagi calon konsumen.

[2] Marimin, 2004 Teknik dan Aplikasi Pengambilan Keputusan Kriteria Majemuk, Penerbit PT Grassindo, Jakarta

[3] penelitian yang dilakukan Sotir, Sotirovand, Andrey, and Nenov, "Tutorials Expert Choice," Comput. Sci. J., vol. Vol.4 No.1, 2006.

[4] pada penelitian Erikson S.Sinaga, Strategi Process Migrasi Proprietary Software Ke Open Source Software Di Perusahaan Dengan Pendekatan Analytical Hierarchy Process $(A H P)$, Studi Kasus: SGU, Tangerang,.Teknik analisa dalam menentukan bobot prioritas langkah yang hendak dilakukan menggunakan pendekatan Analytical Hierarchy Process (AHP). Sebagai ruang lingkup penulisan tesis, dilakukan penelitian di Swiss German University, Tangerang, yang saat ini sedangmelakukan proses migrasi pemanfaatan software dari proprietary ke open source software.

[5] pada penelitian Lipursari, Anastasia. 2013. Peran Informasi Manajemen (SIM) Dalam Pengambilan Keputusan. Metode pengolahan data adalah suatu proses menerima data sebagai masukan, memproses menggunakan program tertentu, dan mengeluarkan hasil proses data tersebut dalam bentuk informasi.

[6] pada penelitian Sarwindah, 2013. Kajian Pemilihan Software Desain Grafis Untuk Pembelajaran Dengan Metode AHP Pada SMK Muhamadiyah 9. Permasalahan pemilihan software desain grafis di SMK Muhammadiyah 9 merupakan objek penelitian yang menghasilkan jawaban yang di inginkan yaitu software Adobe Photoshop yang menjadi prioritas dan dapat di implementasikan untuk pembelajaran di sekolahan SMK Muhammadiyah 9.

[7] pada Penelitian Tanto, 2014 "Perancangan Sistem Pendukung Keputusan Pemberian Kredit Pemilikan Rumah (Kpr) Dengan Metode Simple Additive Weighting" .Metode SAW pemberian KPR memiliki beberapa kriteria yang menjadi dasar pengambilan keputusan antara lain character, capacity, capital, collateral dan condition. Hasil penelitian ini adalah membuat aplikasi sistem pendukung keputusan pemberian KPR untuk memberikan kemudahan dalam pengambilan keputusan pemberian KPR.

[8] pada penelitian Sarwindah, 2016. Sistem Informasi Manajemen Pemesanan Buku pada TOKO BUKU NURIS, Jurnal TEKNOSI, 2(2), pp. 77-84. Untuk membantu dan mengawasi kegiatan pemesanan, maka diperlukan dukungan sistem informasi yang baik, sehingga dapat mengikuti perkembangan usaha yang sedang berkembang.

[9] pada penelitian Butar-Butar, Oktovantua Tp. 2015. Sistem Pendukung Keputusan Rekomendasi Penerima Bantuan Siswa Miskin (BSM) Dengan Metode Simple Additive Weighting (SAW) (Studi Kasus: SMP N2 Tarabintang). Hasil akhir dari penelitian ini didapatkan bahwa sistem pendukung keputusan dengan metode SAW. Mampu mengatasi permasalahan dalam menyeleksi calon penerima Bantuan Siswa Miskin (BSM).

[10] pada penelitian Adianto, Tomy Reza, dkk. 2017. Sistem Pendukung Keputusan (SPK) Pemilihan Rumah Tinggal di Perumahan Menggunakan Metode Simple Additive Weighting (SAW) (STUDI KASUS: KOTA SAMARINDA). Metode Simple Additive Weighting (SAW) merupakan salah satu metode untuk penyelesaian masalah multi-attribute decision making. Konsep dasar metode SAW adalah mencari penjumlah anter bobot dengan rating kinerja pada setiap alternatif pada semua atribut.

[11] pada penelitian Haerani, Ellin dan Ramdaril. 2017. Sistem Pendukung Keputusan Pendistribusian Zakat pada BAZNAS Kota Pekanbaru Menggunakan Fuzzy Multiple Attribute Decission Making (FMADM) dan Simple Additive Weighting (SAW Pada sistem ini akan melakukan pengolahan terhadap data masukan yang diberikan sehingga menghasilkan 
keluaran data berupa mustahik yang memiliki nilai $\mathrm{V}$ tertinggi yang otomatis menjadi mustahik yang direkomendasikan untuk mendapatkan zakat sesuai dengan program kerja yang ada.

[12] pada penelitian sebelumnya penelitian Sarwindah (2018). Sistem Penunjang Keputusan Pemilihan Perumahan Subsidi Berdasarkan Kebutuhan Konsumen dengan metode AHP. Dengan mengacu kepada solusi Analytical Hierarki Process (AHP) dalam membantu membuat keputusan, seorang decision maker dapat mengambil keputusan tentang perumahan yang sesuai dengan yang dinginkan secara cepat dengan membandingkan semua kriteria yang ada. Berdasarkan hasil analisis dan kuisioner yang telah di edarkan pada responden didapatlah kriteria tertinggi adalah kualitas bangunannya yang kokoh menjadi prioritas utama konsumen.

Pada penelitian ini teknik analisa dalam menentukan bobot prioritas adalah langkah yang hendak dilakukan menggunakan pendekatan Analytical Hierarchy Process (AHP). Dengan tujuan yang ingin dicapai adalah membuat sistem pendukung keputusan pemberian kelayakan kredit kepada konsumen dengan menerapkan kriteria penilaian kelayakan kredit yaitu penghasilan (slip gaji), jumlah tanggungan (kartu keluarga), domisi (KTP) disertai bobot penilaian pada setiap kriteria agar dapat membantu Credit Analyst dalam kegiatan pengambilan keputusan konsumen layak kredit

\section{METODE PENELITIAN}

Dalam penelitian ini penulis menggunakan metode penelitian statistik deskriptif. Metode statistik deskriptif yaitu metode dengan pendekatan kuantitatif mengenai fakta-fakta, objek serta sifat dari permasalahan dan kebutuhan yang dikumpulkan kemudian dianalisis sehingga menghasilkan kesimpulan dari deskripsi secara sistematis, faktual dan akurat. Dalam perancangan perangkat lunak, penelitian ini menggunakan metode $S D L C$.

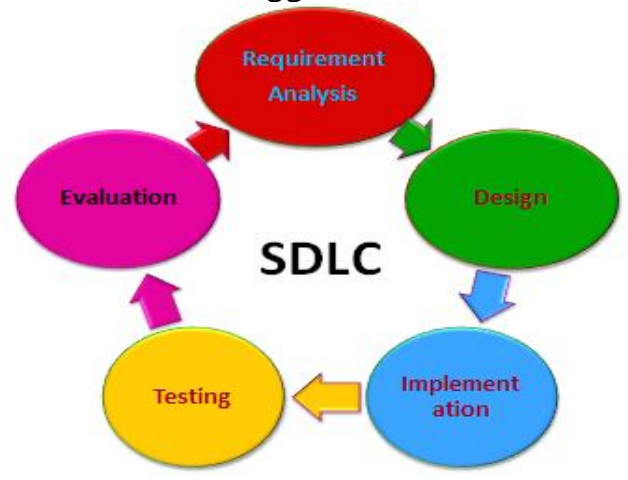

Gambar 1. Metode SDLC (System Development Life-Cycle)

Menurut Prof. Dr. Sri Mulyani, AK., CA. (2017) SDLC adalah proses logika yang digunakan oleh seorang analis sistem untuk mengembangkan sebuah sistem informasi.

\subsection{Metode Pembangunan Sistem}

Setelah merumuskan kerangka konsep maka dilanjutkan ketahapan Pembangunan Sistem yakni:

1) Analisa Kebutuhan Sistem

Tahap menganalisis data yang telah dikumpulkan merupakan tahapan alisis berkaitan dengan proses dan data yang dibutuhkan oleh sistem. Analisis harus mencakup kebutuhan pengguna, interface, dan fungsi yang dibutuhkan. Hasil analisa yaitu berupa model sistem yang telah terstruktur.

Sarwindah, et., al (Penunjang Keputusan Dalam Kelayakan Pemberian Kredit Motor Pada Mandala Multifinance) 
2) Perancangan Sistem

Berdasarkan kebutuhan sistem yang telah dianalisis maka dilakukan perancangan sistem penunjang keputusan menggunakan metode Analytical Hierarchy Process (AHP), mulai dari menentukan tujuan, menyusun kriteria, menyusun hirarki, melakukan perhitungan perbandingan berpasangan, menghiting elgen value dan menghasilkan rangking prioritas.

3) Implementasi Sistem

Implementasi sistem pada tahap ini, peneliti berfokus pada penerapan metode Analytical Hierarchy Process (AHP) untuk menentukan pemberian kredit kepada nasabah.

4) Pengujian dan Analisis

Pengujian dilakukan terhadap sistem yang telah dibangun. Pengujian ini bertujuan untuk membuktikan konsep dan sesuai kebutuhan pengguna. Pengujian kualitas dari perangkat lunak yang dibangun menggunakan pengujian Mc'Call

5) Penarikan Kesimpulan

Penarikan Kesimpulan dilakukan berdasarkan hasil analisa dan pengujian yang telah dilakukan, apakah hasil dari perancangan sistem dapat menjawab pertanyaan pada rumusan masalah dan sesuai dengan hipotesis serta kebutuhan pengguna.

\section{HASIL DAN PEMBAHASAN}

\subsection{Diagram Sistem Usulan}

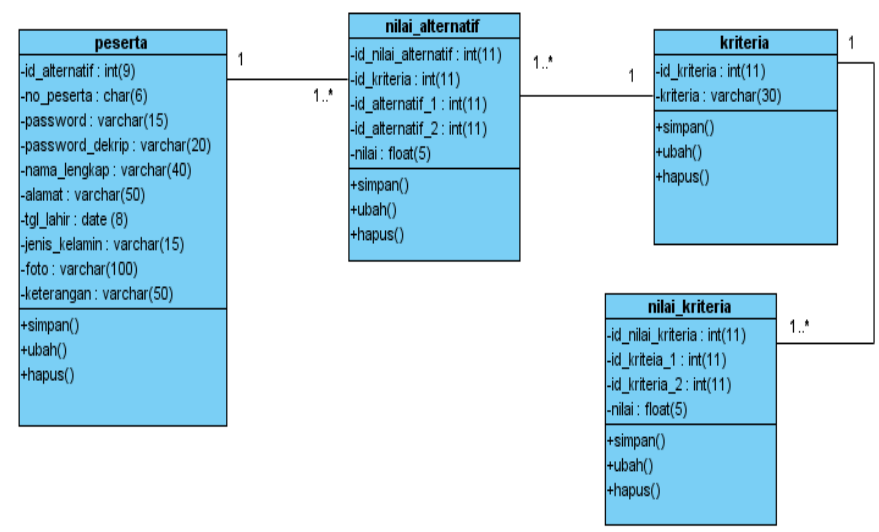

Gambar 2. Class Diagram Sistem Usulan

Berdasarkan gambar 2. Class Diagram yang diusulkan terdapat class sebagai tabel yang didalamnya terdapat atribut-atribut, sedangkan association sebagai relasi antar tabel aribut pada class dengan operasi yang sama.

\subsection{Perhitungan Manual Metode AHP}

1. Perhitungan Faktor Pembobotan Hirarki Untuk Semua Kriteria

Hasil analis prefensi gabungan dari 10 responden menunjukkan bahwa: kriteria penghasilan 4 kali lebih penting kriteria kartu keluarga dan 8 kali lebih penting disbanding dengan kriteria domisili. Sedangkan kartu keluarga 6 kali penting disbanding kriteria domisili. Maka matrik perbandingan hasil referensi diatas adalah: 
Tabel 1. Matrik Faktor Pembobotan Hirarki untuk Semua Kriteria

\begin{tabular}{|l|c|c|c|}
\hline Kriteria & Penghasilan & KartuKeluarga & Domisili \\
\hline Penghasilan & 1 & 6 & 4 \\
\hline KartuKeluarga & $1 / 6$ & 1 & $1 / 3$ \\
\hline Domisili & $1 / 4$ & 3 & 1 \\
\hline
\end{tabular}

Tabel 1 merupakan gambaran matrik faktor pembobotan hirarki untuk semua kriteria. Adapun kriteria yang menjadi acuan yaitu penghasilan, kartu keluarg dan domisili.

Tabel 2. Matriks Faktor Pembobotan Hiraki untuk Semua Kriteria yang Disederhanakan

\begin{tabular}{|l|c|c|c|}
\hline \multicolumn{1}{|c|}{ Kriteria } & Penghasilan & $\begin{array}{c}\text { Kartu } \\
\text { Keluarga }\end{array}$ & Domisili \\
\hline Penghasilan & 1,000 & 6,000 & 4,000 \\
\hline $\begin{array}{l}\text { Kartu } \\
\text { Keluarga }\end{array}$ & 0,167 & 1,000 & 0,333 \\
\hline Domisili & 0,250 & 3,000 & 1,000 \\
\hline$\sum$ & 1,417 & 10 & 5,333 \\
\hline
\end{tabular}

Tabel 2 merupakan tabel pembobotan hirarki untuk semua kriteria yang telah disederhanakan dan kemudian menjumlahkan dari masing-masing kriteria.

Tabel 3. Matrik Faktor Pembobotan Hirarki untuk Semua Kritera yang Dinormalkan

\begin{tabular}{|l|c|c|c|c|}
\hline \multicolumn{1}{|c|}{ Kriteria } & Penghasilan & $\begin{array}{c}\text { Kartu } \\
\text { Keluarga }\end{array}$ & Domisili & $\begin{array}{c}\text { Vector } \\
\text { Eigen }\end{array}$ \\
\hline Penghasilan & 0,649 & 0,571 & 0,727 & 0,649 \\
\hline $\begin{array}{l}\text { Kartu } \\
\text { Keluarga }\end{array}$ & 0,108 & 0,095 & 0,061 & 0,088 \\
\hline Domisili & 0,162 & 0,286 & 0,182 & 0,21 \\
\hline
\end{tabular}

Tabel 3 merupakan tabel pembobotan hirarki untuk semua kriteria dengan unsur-unsur pada tiap kolom dibagi dengan jumlah total pada kolom yang bersangkutan, maka akan diperoleh bobot relatif yang dinormalkan. Nilai vektor eigen dihasilkan dari rata-rata nilai bobot relative untuk tiap baris.

$(\lambda \operatorname{Max})=(1,417 \times 0,649)+(10 \times 0,088)+(6 \times 0,21)$

$=3,06$

Pada persamaan 1 dijelaskan bahwa untuk mencari nilai eigen maksimum ( $\lambda$ maksimum) didapat dengan menjumlahkan hasil perkalian jumlah kolom dengan vektor eigen.

$$
C I=\frac{\lambda \operatorname{Max}-\mathrm{n}}{\mathrm{n}-1}=\frac{3,06-3}{3-1}=\frac{0,06}{2}=0,03
$$

Pada persamaan 2 dihitung nilai indeks konsistensi. Dimana Matrik berordo 4 (yakni terdiri dari 3 kriteria)

$$
C R=\frac{C I}{R I}=\frac{0,030}{0,900}=0,033<0,100
$$

Pada persamaan 3 mencari nilai CR. Dimana untuk $\mathrm{n}=3, R I=0,900$ (Tabel Saaty). dimana $C R<0,100$ berarti prefensi responden adalah konsisten.

Hasil perhitungan tabel diatas menunjukan bahwa kriteria yang paling penting bagi nasabah dalam pengajuan kredit adalah:

a. Penghasilan dengan bobot 0,649 atau $64,9 \%$,

Sarwindah, et., al (Penunjang Keputusan Dalam Kelayakan Pemberian Kredit Motor Pada Mandala 
b. Kartu keluarga dengan nilai bobot 0,088 atau $8,8 \%$,

c. Domisili adalah 0,21 atau $21 \%$

\section{Vektor Prioritas}

Baris dikalikan dan selanjutnya ditarik akar berpangkat $\boldsymbol{n}$. Hasil dari setiap baris ii kemudian dibagi dengan jumlah dari hasil semua baris.

Tabel 4. Matriks Vector Prioritas

\begin{tabular}{|l|c|c|c|}
\hline \multicolumn{1}{|c|}{ Kriteria } & Penghasilan & $\begin{array}{c}\text { Kartu } \\
\text { Keluarga }\end{array}$ & Domisili \\
\hline Penghasilan & 1,000 & 6,000 & 4,000 \\
\hline Kartu Keluarga & 0,167 & 1,000 & 0,333 \\
\hline Domisi & 0,250 & 3,000 & 1,000 \\
\hline
\end{tabular}

Tabel 4 merupakan nilai matriks vektor prioritas yaitu dengan kriteria penghasilan, kartu keluarga dan domisili.

Dengan demikian dapat diperoleh vektor prioritasnya, yaitu:

$4 \sqrt{ } 1 \mathrm{X} 6 \mathrm{X} 4=2,213$

$4 \sqrt{ } 0,167 \times 1,000 \times 0,333=0,485$

$4 \sqrt{ } 0,25 \times 3 \times 1=0,930$

$\Sigma=3,628$

Pada persamaan 4, 5 dan 6 mencari nilai vector prioritasnya yaitu dengan cara nilai pada setiap baris dikalikan dan selanjutnya ditarik akar berpangkat $\mathbf{n}$.

Vektor Prioritas:

$2,213: 3,628=0,609$

$0,485: 3,628=0,133$

$0,930: 3,628=0,256$

\subsection{Tahap Desain dan Pembuatan Prototype}

Berikut ini hasil desain telah dibangun menggunakan Metode AHP yaitu:

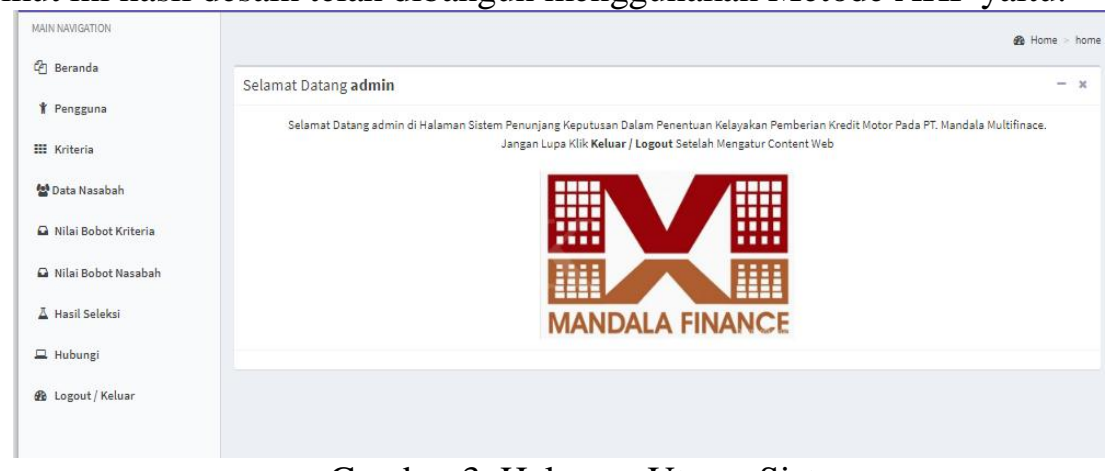

Gambar 3. Halaman Utama Sistem

Gambar 3 merupakan halaman utama rancangan yang dibangun pada sistem penunjang keputusan dalam kelayakan pemberian kredit motor pada mandala multifinance. 


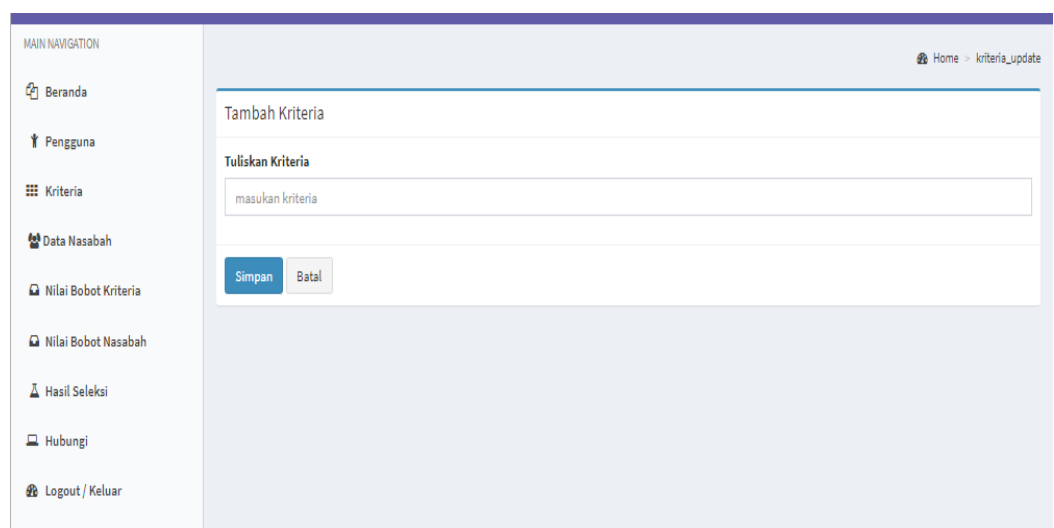

Gambar 4. Halaman Form Data Kriteria

Gambar 4 merupakan halaman form Kriteria untuk menginput kriteria seperti kriteria penghasilan, kartu keluarga dan domisili.

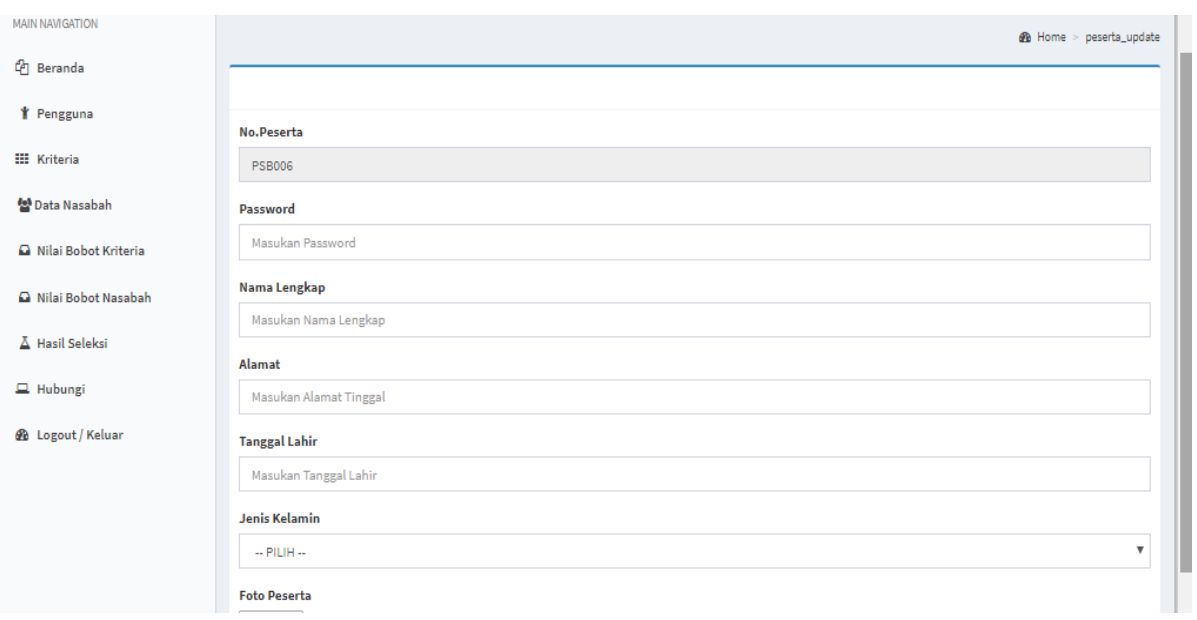

Gambar 5. Halaman Form Data Nasabah

Gambar 5 merupakan halaman form Nasabah untuk menginput data nasabah seperti nama lengkap, alamat, tanggal lahir dan jenis kelamin.

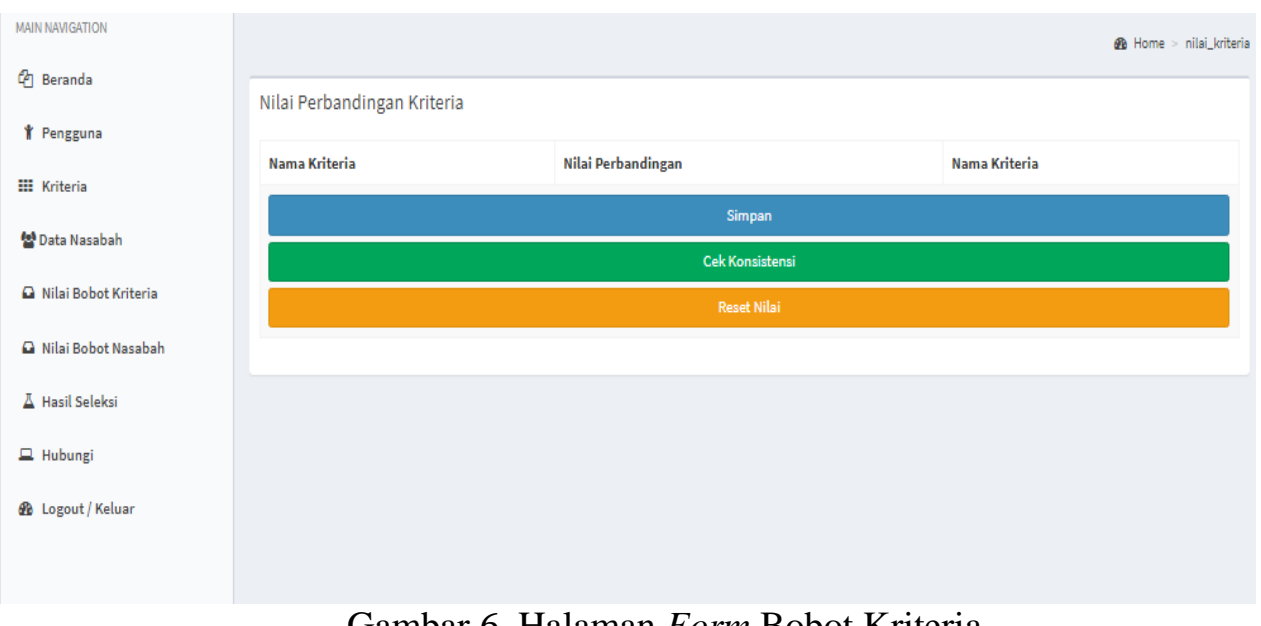

Gambar 6. Halaman Form Bobot Kriteria 
Gambar 6 merupakan halaman form Bobot Kriteria untuk pembobotan hirarki semua kriteria dengan unsur-unsur pada tiap kolom dibagi dengan jumlah total pada kolom yang bersangkutan, maka akan diperoleh bobot relatif yang dinormalkan.

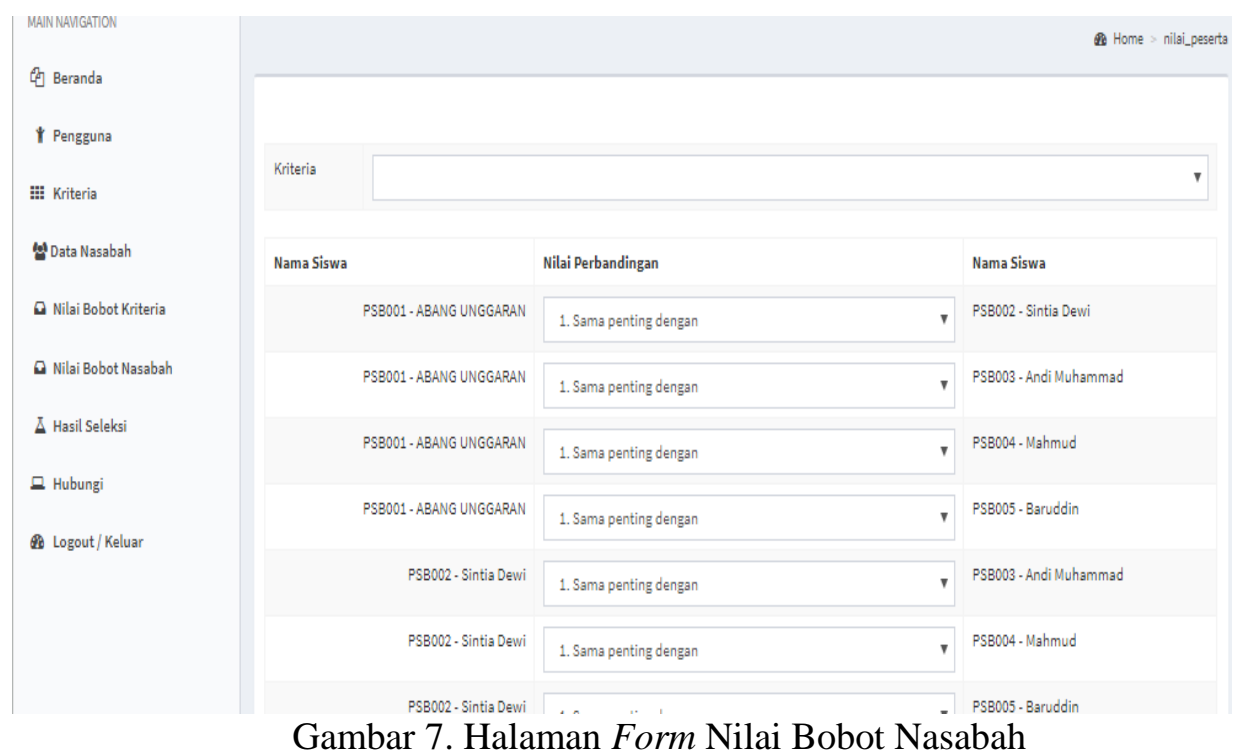

Gambar 7 merupakan halaman form Bobot Nasabah untuk nilai perbandingan nasabah yang layak kredit.

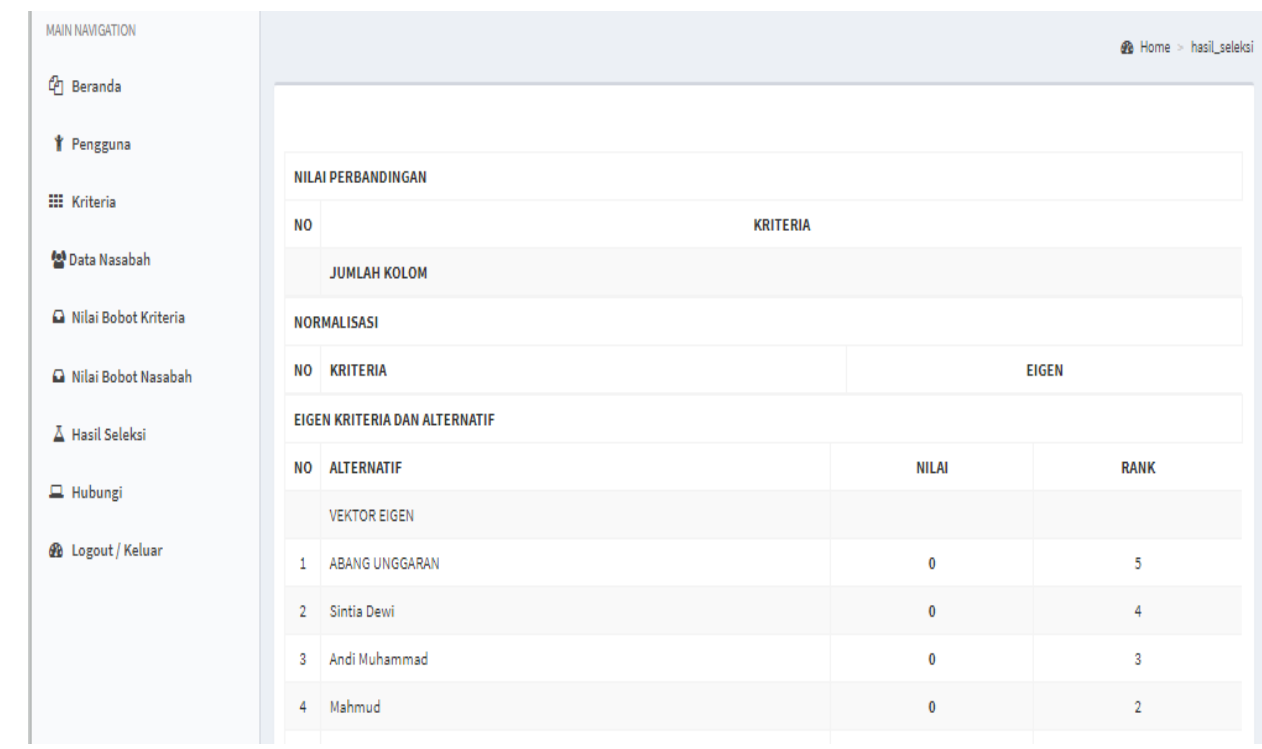

Gambar 8. Halaman Form Hasil Seleksi

Gambar 8 merupakan halaman form Hasil Seleksi didapatkan dari gabungan bobot kriteria dan bobot nasabah. Hasil perhitungan kriteria yang paling penting bagi nasabah dalam pengajuan kredit pada mandala finance. 


\section{KESIMPULAN}

Penelitian ini memiliki kesimpulan Prototype yang dibangun telah berhasil membantu PT. Mandala Multifinance dalam menentukan kelayakan pemberian kredit motor pada nasabah. Tampilan sistem masih perlu perbaikan lebih lanjut serta desain yang menarik. Analisa dan perancangan digambarkan menggunakan tool UML (Unified Modeling Languange). Manfaat dari penelitian ini adalah untuk membantu Credit Analyst dalam kegiatan pengambilan keputusan konsumen layak kredit.

\section{SARAN}

Berdasarkan hasil penelitian saat ini, Perlu adanya penambahan kriteria penilaian sehingga dapat menghasilkan data yang lebih akurat. Adanya pengujian tentang hasil kinerja sistem seperti penggunaan pengukuran Mc'Calls. Perlu adanya penelitan dengan membandingkan dua metode Sistem Penunjang Keputusan sehingga dapat membandingkan hasil antara dua metode Sistem Penujang Keputusan tersebut.

\section{DAFTAR PUSTAKA}

[1] A. Amborowati, "Sistem Penunjang Keputusan Pemilihan Perumahan dengan Metode AHP Menggunakan Expert Choice," AMIKOM, 2004.

[2] Marimin, Teknik dan Aplikasi Pengambilan Keputusan Kriteria Majemuk. PT Grassindo, Jakarta. 2004.

[3] Sotir, Sotirov, Andrey, and Nenov, "Tutorials Expert Choice," Comput. Sci. J., Vol. Vol.4 No.1, 2006.

[4] E. Sinaga and Erikson, Strategi Process Migrasi Proprietary Software ke Open Source Software di Perusahaan Dengan Pendekatan Analytical Hierarchy Process (AHP), Studi Kasus: SGU. Tanggerang, 2007.

[5] Lipursari and Anastasia, "Peran Informasi Manajemen (SIM) Dalam Pengambilan Keputusan,” J. STIE SEMARANG, Vol. 5, No, pp. 26-37, 2013.

[6] Sarwindah, "Kajian Pemilihan Software Desain Grafis untuk Pembelajaran Dengan Metode AHP pada SMK Muhamadiyah 9," SEMNASTEKNOMEDIA, 2013.

[7] Tanto, "Perancangan Sistem Pendukung Keputusan Pemberian Kredit Pemilikan Rumah (Kpr) Dengan Metode Simple Additive Weighting," 2014.

[8] Sarwindah, "Sistem Informasi Manajemen Pemesanan Buku pada TOKO BUKU NURIS,” J. TEKNOSI, pp. 77-84, 2016.

[9] Butar-Butar and Oktovantua, "Sistem Pendukung Keputusan Rekomendasi Penerima Bantuan Siswa Miskin (BSM) Dengan Metode Simple Additive Weighting (SAW) (Studi Kasus: SMPN 2 Tarabintang)," Inform. Budi Darma, Vol. IX Nomor:, pp. 162-165, 2016.

Sarwindah, et., al (Penunjang Keputusan Dalam Kelayakan Pemberian Kredit Motor Pada Mandala Multifinance) 
[10] Adianto and T. dkk Reza, "Sistem Pendukung Keputusan (SPK) Pemilihan Rumah Tinggal di Perumahan Menggunakan Metode Simple Additive Weighting (SAW) (STUDI KASUS: KOTA SAMARINDA),” Pros. Semin. Ilmu Komput. dan Teknol. Inf., Vol. 2, No, рр. 197-201, 2017.

[11] Haeran Ellin and Ramdaril, . "Sistem Pendukung Keputusan Pendistribusian Zakat pada BAZNAS Kota Pekanbaru Menggunakan Fuzzy Multiple Attribute Decission Making (FMADM) dan Simple Additive Weighting (SAW)," J. Ilm. Tek. Inform., Vol.10 No., pp. 159-168, 2017.

[12] Sarwindah, "Sistem Penunjang Keputusan Pemilihan Perumahan Subsidi Berdasarkan Kebutuhan Konsumen Dengan Metode AHP," KNSI 2018, pp. 668-673,. 